\title{
A Multifaceted Evaluation of National Off-label Neurology Applications
}

\section{Ulusal Endikasyon Dışı Nöroloji Başvurularının Çok Yönlü Değerlendirilmesi}

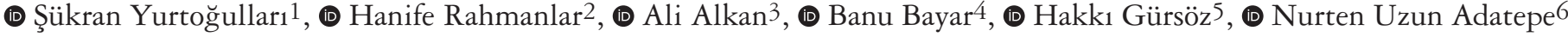 \\ ${ }^{1}$ Ankara Ataturk Training and Research Hospital, Clinic of Neurology, Ankara, Turkey \\ 2Ministry of Health Turkish Medicines and Medical Devices Agency, Economic Evaluations and Drug Supply Management, Ankara, Turkey \\ 3Ministry of Health Turkish Medicines and Medical Devices Agency, Pharmaceutical Supply Management, Ankara, Turkey \\ 4Ministry of Health Turkish Medicines and Medical Devices Agency, Head of Department, Ankara, Turkey \\ 5Ministry of Health Turkish Medicines and Medical Devices Agency, President of the Institution, Ankara, Turkey \\ 6Istanbul University-Cerrahpasa, Cerrahpasa Faculty of Medicine, Department of Neurology, Istanbul, Turkey
}

\begin{abstract}
Objective: Off-label drug use (OLDU) of neurologic diseases is approved by a regulatory authority, the Turkish Medicines and Medical Devices Agency (TMMDA) in Turkey. It was aimed to investigate the most common neurologic drugs relevant to off-label prescribing and the most prescribed diagnosis, demographic and medical characteristics of patients with OLDU applications in Turkey.

Materials and Methods: Four years "TMMDA"s electronic OLDU application records, 9,758 applications in total, were evaluated retrospectively. Information regarding patients' demographic characteristics, diagnoses, ordered drugs, and institutions were evaluated.

Results: The most OLDU applications were mostly made in 2015, the majority of which were associated with neurodegenerative diseases. The mean age of the patients was 41.6 years and $65 \%$ were female. Some $62.1 \%$ of off-label drug application patients' age range was found as $18-64$ years. The most common applications were from the Marmara region with 36\% and neurology clinics of university hospitals with 81\%. Multiple sclerosis (MS) was the most common diagnosis and the most frequently used group of drugs was disease-modifying drugs used in the treatment of MS.

Conclusion: Based on the four-year survey of OLDU applications for adult neurologic patients showed that unlicensed drug prescriptions were high. There are very few studies on the result of OLDU applications in neurology worldwide. We believe that this study will be a guide to neurologists with off-label application processes and the results in our country and will make a significant contribution to the literature.
\end{abstract}

Keywords: Off-label drug use, neurologic diseases, multiple sclerosis, chronic migraine

Öz

Amaç: Nörolojik hastalıklarda endikasyon dışı ilaç kullanımı Türkiye'de düzenleyici otorite olan Türkiye İlaç ve Tibbi Cihaz Kurumu (TíTCK) tarafından onaylanmaktadır. Bizde bu çalışma ile ülkemizde endikasyon dışı en sık reçetelenen nörolojik ilaçlar ve tanıların saptanmasını, bu tedavileri alan hastaların demografik ve medikal özelliklerini araştırmayı amaçladık.

Gereç ve Yöntem: TíTCK'nın dört yıllık elektronik endikasyon dışı kayıtları (toplam 9,758 başvuru) retrospektif olarak de ğerlendirilmiştir. Hastaların demografik özellikleri, tanıları, reçetelenen ilaçlar, kurumları incelenmiştir.

Bulgular: En sık endikasyon dışı başvuru 2015 yılında yapılmıştır ve başvuruların çoğunluğu nörodejeneratif hastalıklarla ilişkilidir. Hastaların yaş ortalaması 41,6 ve \%65'ini kadınlar oluşturmaktadır. Endikasyon dışı başvuru yapılan hastaların \%62,1'inin yaş aralığı 18-64 olarak saptanmıştır. En sık başvurular \%36 ile Marmara Bölgesi’nden ve \%81 ile üniversite hastanesi nöroloji kliniklerinden yapılmıştır. Multipl skleroz (MS) en yaygın başvuru yapılan tanıdır ve en sık başvuru yapılan ilaç grubu da MS tedavisinde kullanılan hastalık modifiye edici ilaçlardır.

Sonuç: Erişkin nöroloji alanında yapılan dört yıllık endikasyon dışı başvurular incelendiğinde ruhsatsız ilaç başvurularının yüksek olduğu saptandı. Dünya çapında çok az sayıda nöroloji endikasyon dışı ilaç kullanım sonuçları ile ilgili çalışma bulunmaktadır. Biz bu çalışmamızla ülkemizde yapılan endikasyon dışı başvuru süreçleri ve sonuçları ile kılavuz olduğumuzu ve literatüre önemli katkı sağladığımızı düşünmekteyiz.

Anahtar Kelimeler: Endikasyon dışı ilaç kullanımı, nörolojik hastalıklar, multipl skleroz, kronik migren

Address for Correspondence/Yazışma Adresi: Şükran Yurtoğulları MD, Ankara Ataturk Training and Research Hospital, Clinic of Neurology, Ankara, Turkey Phone: +90 5332508298 E-mail: sukranyurtogullari@hotmail.com ORCID: orcid.org/0000-0003-2213-4299

Received/Geliş Tarihi: 16.10.2019 Accepted/Kabul Tarihi: 23.01.2020

${ }^{\circ}$ Copyright 2020 by Turkish Neurological Society

Turkish Journal of Neurology published by Galenos Publishing House. 


\section{Introduction}

Off-label drug use (OLDU) describes the use of a medicinal product in an unapproved dosage, age group, or route of administration and for an indication other than those stated in the licence, which will have undergone clinical trials for this. Because the drug licensing process is complex, high-priced, and time-consuming, the additional indication is considered to be an extra cost $(1,2)$. Writing off-label prescriptions is legal in many countries worldwide. Orphan patients and patients with cancer mostly rely on OLDU treatments. Although OLDU ratios vary among different countries, the worldwide rates declared are between $18 \%$ and $36 \%$ in adults $(3,4,5,6)$.

In Turkey, the OLDU system is used as per the delegated legislation dated 2011 (no: 663). The Turkish Medicines and Medical Devices Agency (TMMDA) has the authority to evaluate applications for three conditions;

i) Procurement of unlicensed drugs or licensed drugs (but are currently not available in the Turkish market, unreachable drugs) which will be reimbursed by the social security institution. Then these allowed drugs will be imported by the Turkish Pharmacists' Association on an individual patient basis.

ii) Use of licensed medicines out of their prospectus,

iii) In urgent conditions, collective procurement of unlicensed drugs or licensed unreachable drugs.

Based on one of these facts, physicians can apply for these conditions to TMMDA. OLDU Guideline" released by the TMMDA will be beneficial (http://www.titck.gov.tr/Mevzuat/).

Physicians submit their justified applications including a detailed history, neurologic examination, and the results of analyses, imaging, and laboratory findings concerning the diagnosis in question, together with the signed and current consent form obtained from patients. Scientific advisory committees comprising physicians with corresponding specialities suggested by the TMMDA and approved by the ministry of health evaluate the applications. If the applications are considered to be acceptable, approval for use would be given, initially for 3 months and/or one course of treatment. Unlicensed drugs are imported by the Turkish Pharmacists' Association in amounts that correspond to 3 months- and/or one course of treatment and supplied to the patient. Licensed drugs can be obtained from pharmacies with a drug use report and prescription. At the end of the 3 months, if the applicant physician concludes that the drug is beneficial for the patients, the efficacy of the drug for this patient is revaluated upon a detailed submission including the parameters that improved, as well as any adverse effect reporting.

Neurologic diseases usually involve complex treatments. OLDU is quite common in these neurologic diseases because of some neurologic conditions have limited treatment options. However, there are very few studies on OLDU in adult neurologic diseases in the world. Our study is the second study in the literature on this topic (2). With this study, it is intended to establish good guidance for our physicians by reviewing the applications in neurology in our country and to contribute to the literature by offering a comparison with similar uses across the world. The most commonly used off-label drugs and demographics and medical background of patients using these drugs are presented as part of the study.

\section{Materials and Methods}

Our study was performed by retrospectively reviewing the medical records of applications in the neurology field submitted to the TMMDA from all cities in our country between January 2013 and January 2017. Among these applications, electronic patient records in the TMMDA computer database were assessed. Commitment that patient data privacy would be obtained and that the data would be used only for scientific purposes was made and permission from the TMMDA was obtained for the study. Approval of the Ethics Board of the Medical Faculty of Cerrahpasa University was received on 04/08/2018 (45103048-604.01.0145803).

Parameters such as patients' demographic characteristics, diagnoses, requested drugs, institutions (but not identifiers of patients or physicians) were obtained from the OLDU application records in the TMMDA database. Patients' ID numbers were converted to codes, and thus replicate applications made for the same patient and the same drug were avoided. Diagnoses were classified according to the International Classification of Disease. Drugs were grouped using the anatomic, therapeutic, and chemical classification system. Patients were compared by age, sex, insurer, and the three most commonly prescribed off-label drugs. In addition, the three diagnoses for which applications were made most frequently were analyzed.

\section{Statistical Analysis}

The chi-square test was used for the statistical analyses using the SPSS 16.0 software. For comparisons, statistical significance was set at $\mathrm{p}<0.05$.

\section{Results}

Data covering a period of four years were analyzed in detail. Based on the analyses, a total of 9.758 patients, 1.867 from 2013, 2.945 from 2014, 2.174 from 2015, and 2.772 from 2016, were included in the study (Table 1, 2, 3, 4). Of these patients, 39\% were male and $61 \%$ were female. Of the applications, $87 \%$ were approved and $13 \%$ were rejected. Approved applications were evaluated concerning the reason, sex, age range, and method of practice. For OLDU applications, the most commonly permitted period of therapy was in the range of 90-120 days (70.0\%). Thirtytwo percent of the rejected applications were not approved due to missing documents, $24 \%$ were rejected because all licensed options had not been administered, and $9 \%$ were rejected due

Table 1. Distribution of applications for neurologic drugs submitted to the Turkish Medicines and Medical Devices Agency between January 2013 and January 2014

\section{Approval Rejection}

$\begin{array}{llllll}\begin{array}{l}2013 \text { Top three } \\ \text { drugs }\end{array} & \% & \mathrm{n} & \% & \mathrm{n} & \begin{array}{l}\text { Statistics } \\ \text { (chi-square) }\end{array} \\ \begin{array}{l}\text { Fingolimod (L04AA27) } \\ (\mathrm{n}=1058)\end{array} & 99 & 1052 & 1 & 6 & \\ \begin{array}{l}\text { Botulinum toxin A } \\ \text { (M03AX01) (n=292) }\end{array} & 97 & 282 & 3 & 10 & \mathrm{p}<0.05 \\ \begin{array}{l}\text { Mycophenolate mofetil } \\ \text { (L04AA06) (n=137) }\end{array} & 96 & 131 & 4 & 6 & \\ \begin{array}{l}\text { Total }(\mathrm{n}=1487) \\ \end{array} & 99 & 1465 & 1 & 22 & \end{array}$


to a lack of efficacy and safety data from randomized controlled clinical trials. Others were rejected because drug applications' clinical features failed to meet the eligibility criteria (ambulation, pregnancy, age, Expanded Disability Status scale), which are defined by commissions constituted by related specialists.

The region that submitted the most applications was the Marmara Region with 36\%, followed by the Central Anatolia with 28\%, the Aegean Region with 16\%, the Mediterranean Region with $8 \%$, the Black Sea Region with $5 \%$, the Eastern Anatolia Region with $4 \%$, and the Southeastern Anatolia Region with $3 \%$, respectively. On an institutional basis, application rates were

Table 2. Distribution of applications for neurologic drugs submitted to the Turkish Medicines and Medical Devices Agency between January 2014 and January 2015

\begin{tabular}{lccccc|} 
& \multicolumn{2}{c}{ Approval } & Rejection & $\begin{array}{l}\text { Statistics } \\
\text { (chi-square) }\end{array}$ \\
$\begin{array}{l}\text { 2014 Top three } \\
\text { drugs }\end{array}$ & $\%$ & $\mathbf{n}$ & $\%$ & $\mathrm{n}$ & \\
$\begin{array}{l}\text { Botulinum toxin A } \\
\text { (M03AX01) (n=57) }\end{array}$ & 77 & 446 & 23 & 131 & \\
$\begin{array}{l}\text { Dimethyl fumarate } \\
\text { (N07XX09) (551) }\end{array}$ & 94 & 517 & 6 & 34 & $\mathrm{p}<0.05$ \\
$\begin{array}{l}\text { Fingolimod } \\
\text { (L04AA27) (n=418) }\end{array}$ & 91 & 382 & 9 & 36 & \\
Total $(\mathrm{n}=1546)$ & 87 & 1345 & 13 & 201 & \\
\hline
\end{tabular}

Table 3. Distribution of applications for neurological drugs submitted to the Turkish Medicines and Medical Devices Agency between January 2015 and January 2016

\begin{tabular}{|c|c|c|c|c|c|}
\hline \multirow[b]{2}{*}{$\begin{array}{l}2015 \text { Top three } \\
\text { drugs }\end{array}$} & \multicolumn{2}{|c|}{ Approval } & \multicolumn{2}{|c|}{ Rejection } & \multirow{2}{*}{$\begin{array}{l}\text { Statistics } \\
\text { (chi-square) }\end{array}$} \\
\hline & $\%$ & $\mathrm{n}$ & $\%$ & $\mathrm{n}$ & \\
\hline $\begin{array}{l}\text { Dimethyl fumarate } \\
(\text { N07XX09) }(n=1008)\end{array}$ & 83 & 832 & 17 & 176 & \multirow{4}{*}{$\mathrm{p}<0.05$} \\
\hline $\begin{array}{l}\text { Botulinum toxin A } \\
(\text { M03AX01) }(n=692)\end{array}$ & 82 & 570 & 18 & 122 & \\
\hline $\begin{array}{l}\text { Fingolimod (L04AA27) } \\
(n=446)\end{array}$ & 81 & 360 & 19 & 86 & \\
\hline Total $(n=2146)$ & 82 & 1762 & 18 & 384 & \\
\hline
\end{tabular}

Table 4. Distribution of applications for neurological drugs submitted to the Turkish Medicines and Medical Devices Agency between January 2016 and January 2017

\begin{tabular}{|c|c|c|c|c|c|}
\hline \multirow[b]{2}{*}{$\begin{array}{l}2016 \text { Top three } \\
\text { drugs }\end{array}$} & \multicolumn{2}{|c|}{ Approval } & \multicolumn{2}{|c|}{ Rejection } & \multirow{2}{*}{$\begin{array}{l}\text { Statistics } \\
\text { (chi-square) }\end{array}$} \\
\hline & $\%$ & $\mathrm{n}$ & $\%$ & $\mathrm{n}$ & \\
\hline $\begin{array}{l}\text { Natalizumab } \\
(\text { L04AA23) }(n=557)\end{array}$ & 80 & 443 & 20 & 114 & \multirow{4}{*}{$\mathrm{p}<0.05$} \\
\hline $\begin{array}{l}\text { Botulinum toxin A } \\
\text { (M03AX01) }(n=464)\end{array}$ & 83 & 387 & 17 & 77 & \\
\hline $\begin{array}{l}\text { Fingolimod } \\
(\text { L04AA27) }(n=237)\end{array}$ & 88 & 209 & 12 & 28 & \\
\hline Total $(n=1258)$ & 83 & 1039 & 17 & 219 & \\
\hline
\end{tabular}

$81 \%, 13 \%$, and $6 \%$ in university hospitals, education and research hospitals, and private hospitals, respectively.

The three most common diagnoses and the three most demanded drugs were analysed. In 2013 for diagnosis, multiple sclerosis (MS) ranked first according to the number of applications, followed by migraine and myasthenia gravis (MG); the highestranked drug was fingolimod, followed by botulinum toxin $\mathrm{A}$ and mycophenolate mofetil (MMF). In 2014, chronic migraine (CM) ranked first, MS ranked second, and MG ranked third; the rank order of drugs was botulinum toxin, dimethyl fumarate, and fingolimod. In 2015, the diagnoses with the most frequent applications were the same. Drugs by order of frequency were dimethyl fumarate, botulinum toxin A, and fingolimod. In 2016, the trend remained the same for diagnoses for drugs natalizumab, botulinum toxin and fingolimod were the subjects of applications most frequently submitted (Table 5, 6).

The chronologic order of authorization of MS drugs in our country is as follows: natalizumab in October 2014, fingolimod in November 2015, and dimethyl fumarate in December 2016. Off-label applications for drugs decline after they are authorized, which is shown in tables as annual statistics.

In our study, the applications were most frequently made for patients with MS. The drugs with the most frequent OLDU applications by years in MS is presented in the graphs below (Figure 1, 2, 3, 4). Another common diagnosis was migraine, and
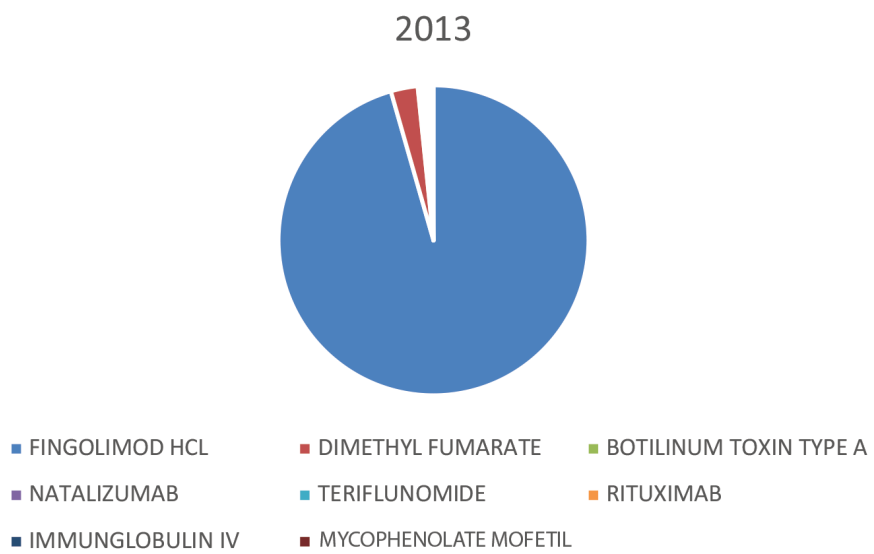

Figure 1. Drugs with OLDU applications for MS in 2013 OLDU: Off-label drug use, MS: Multiple sclerosis

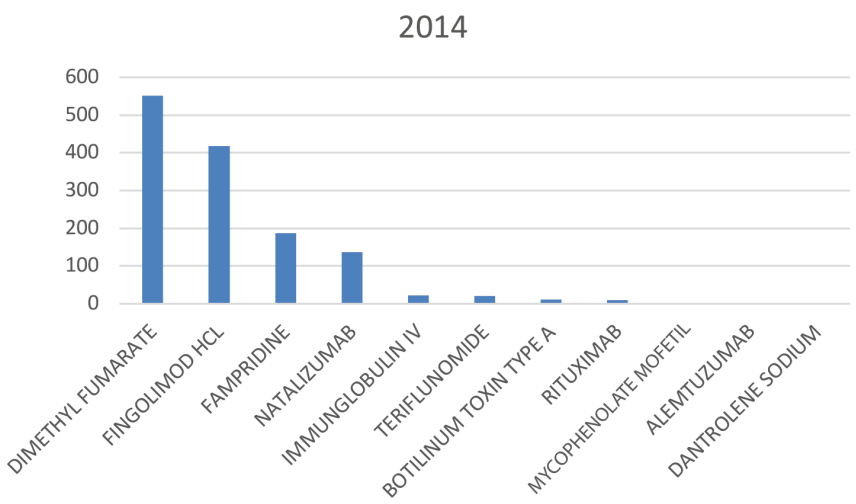

Figure 2. Drugs with OLDU applications for MS in 2014 OLDU: Off-label drug use, MS: Multiple sclerosis 
in that diagnosis, the drug with the highest prevalence of off-label use was botulinum toxin A. OLDU applications for botulinum toxin A by years are presented in a graph (Figure 5).

\section{Discussion}

OLDU applications for neurologic conditions in our country are made for patients who have tried standard treatment options
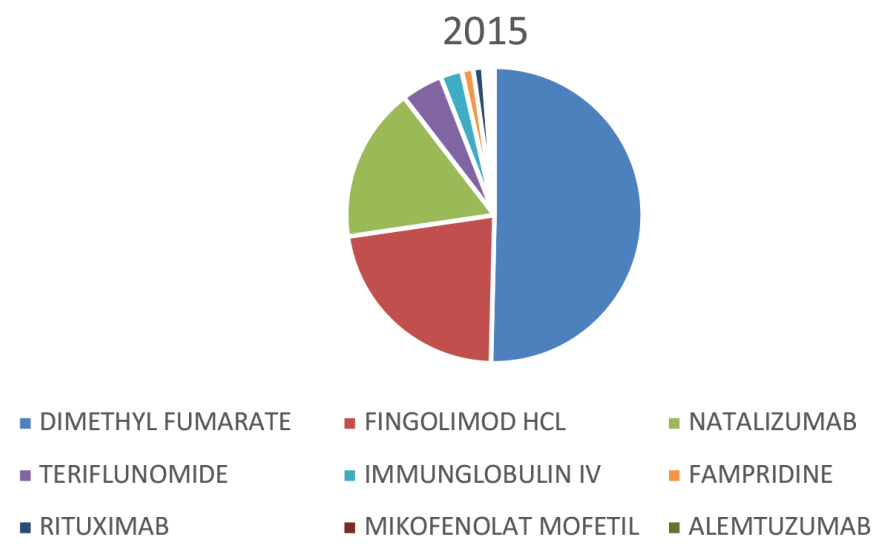

- BOTILINUM TOXIN TYPE A - DANTROLENE SODIUM

Figure 3. Drugs with OLDU applications for MS in 2015 OLDU: Off-label drug use, MS: Multiple sclerosis before the OLDU application is sent in the relevant diagnosis or have conditions that preclude their use. Unlicensed drugs approvals are evaluated provided that there is United States Food and Drug Administration (FDA) and/or European Medicines Agency (EMA) approval by commissions of specialized physicians in accordance with the established criteria specific for diseases and the relevant Legislation in Turkey (7). Legal arrangements governing this topic in our country are similar to those in the United States of America (USA) and Europe (8). The physician obtains the patient's informed

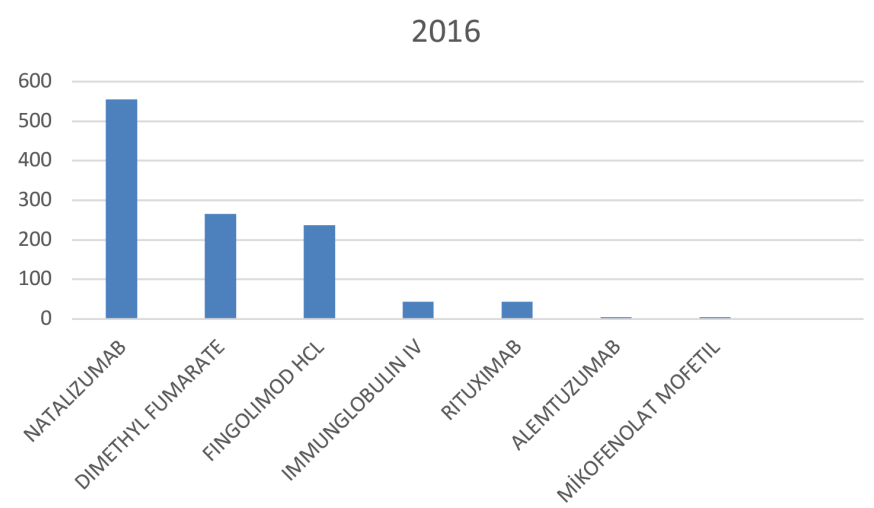

Figure 4. Drugs with OLDU applications for MS in 2016 OLDU: Off-label drug use, MS: Multiple sclerosis

Table 5. Distribution of the most frequent diagnoses in Off-label drug use applications submitted to the Turkish Medicines and Medical Devices Agency between January 2013 and January 2015

\begin{tabular}{|c|c|c|c|c|c|c|}
\hline & & \multicolumn{2}{|c|}{ Approval } & \multicolumn{2}{|c|}{ Rejection } & \multirow{2}{*}{$\begin{array}{l}\text { Statistics } \\
\text { (chi-square) }\end{array}$} \\
\hline & & $\%$ & $\mathrm{n}$ & $\%$ & $\mathrm{n}$ & \\
\hline \multirow{4}{*}{ Top three diagnoses (2013) } & Multiple sclerosis $(G 35)(n=1108)$ & 97.2 & 1077 & 2.8 & 31 & \multirow{4}{*}{$\mathrm{p}<0.05$} \\
\hline & Migraine $(\mathrm{G} 43)(\mathrm{n}=241)$ & 96.3 & 232 & 3.7 & 9 & \\
\hline & Myasthenia gravis $(G 70)(n=119)$ & 91.6 & 109 & 8.4 & 10 & \\
\hline & Total $(n=1468)$ & 96.6 & 1418 & 3.4 & 50 & \\
\hline \multirow{4}{*}{ Top three diagnoses (2014) } & Multiple sclerosis (G35) $(n=1531)$ & 81.3 & 1244 & 18.7 & 287 & \multirow{4}{*}{$\mathrm{p}<0.05$} \\
\hline & Migraine (G43) (n=486) & 75.3 & 366 & 24.7 & 120 & \\
\hline & Myasthenia gravis $(G 70)(n=134)$ & 89.6 & 120 & 10.4 & 14 & \\
\hline & Total $(n=2151)$ & 80.4 & 1730 & 19.6 & 421 & \\
\hline
\end{tabular}

Table 6. Distribution of the most frequent diagnoses in Off-label drug use applications submitted to Turkish Medicines and Medical Devices Agency between January 2015 and January 2017

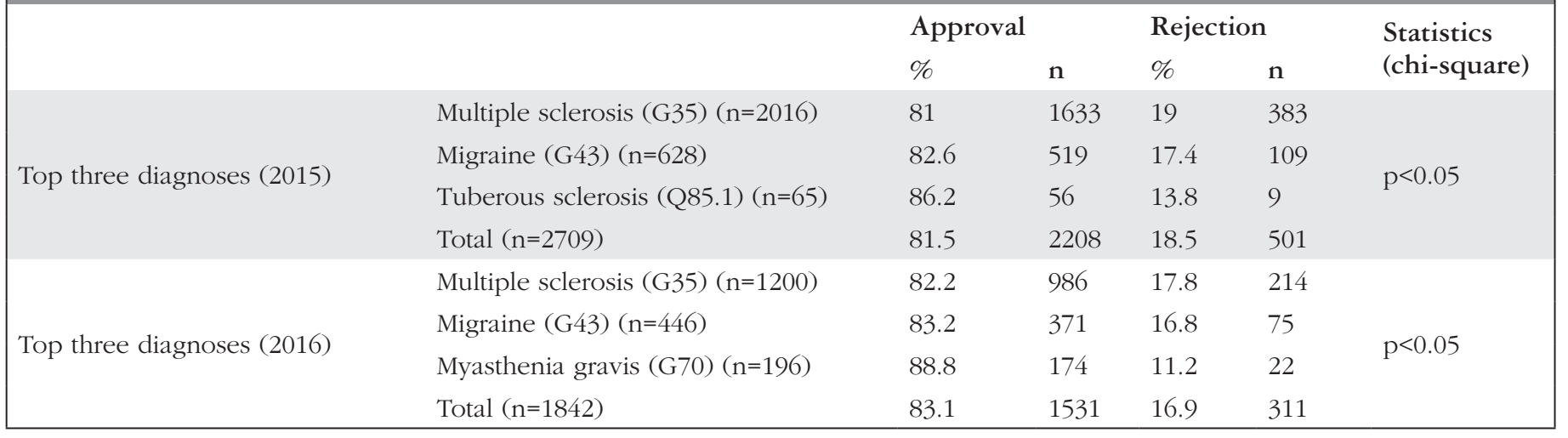




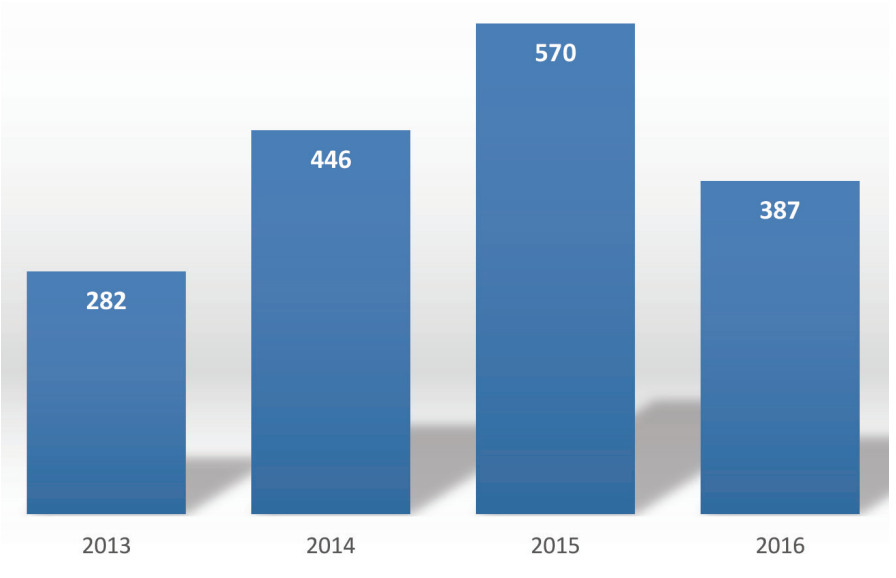

Figure 5. Distribution of botulinum toxin A applications by years OLDU: Off-label drug use, MS: Multiple sclerosis

consent and submits to the Ministry of Health (9). Efficacy, safety, and adverse effects that arise during the use of the applied drug are the applicant physician's responsibilities.

In our study, $87 \%$ of the applications were approved; $13 \%$ were rejected during the four years. The most common cause for disallowance of OLDU applications made during the years studied was that the standard treatment options had not administered, followed by applications being submitted with deficient document.

The diagnosis with the most frequent applications during the years we studied was MS, as also reported from the study by Özdamar et al. (10) in 2011. MS is the most common inflammatory and demyelinating disease of the central nervous system, which starts in early adulthood, progresses with recurrent neurologic dysfunctions, and its etiology is not yet known $(11,12,13)$. Approximately 2.3 million people had a diagnosis of MS in 2013 and the worldwide median prevalence of MS was 33 per 100,000 (in 2013). For example, the highest prevalence in Europe was 189 per 100,000 in Sweden, and the lowest was 22 per 100,000 in Albania. According to this map, the prevalence of MS in Turkey was 20-60/100,000 (14). The incidence of MS in Turkey is estimated as one in every 2000-2500 individuals (15).

OLDU applications for drugs used in MS treatment increase gradually because it affects the young population and may lead to disability if left untreated. The drugs approved in our country, by date of approvals, are respectively natalizumab in September 2014, fingolimod in November 2015, and dimethyl fumarate in December 2016. Natalizumab (Tysabri), fingolimod hydrochloride (Gilenya), and dimethyl fumarate (Tecfidera) were approved by the FDA respectively in November 2004, September 2010, and March 2013. Natalizumab, fingolimod hydrochloride, and dimethyl fumarate were approved by EMA respectively in June 2006, March 2011, and January 2014. Because off-label applications for a drug declines after it is authorized in our country, we believe this had a pronounced impact on the ranking changes in the years we studied.

One of the three most frequent diagnoses was migraine, and one of the three most commonly prescribed drugs was also botulinum toxin A. In 2010, according to Phase III Research Evaluating Migraine Prophylaxis Therapy clinical study's results, the Medicines and Healthcare Products Regulatory Agency in the UK, and later the FDA in USA, approved botulinum toxin A injection therapy for the prevention of headaches in adults with CM. In 2011, also the EMA approved Botox ${ }^{\circledR}$ for treatment of CM $(16,17,18)$.

In July 2011 TMMDA approved Botox for CM prophylaxis. The criteria of use recommended by the National Institute for Health and Care Excellence were based on these criteria. Within this context, botulinum toxin type $\mathrm{A}$ is recommended as an option for the prevention of headaches in adult patients living with $\mathrm{CM}$ (described as headaches on at least 15 days per month of which at least 8 days are with migraine) that has shown no signs of improvement to at least three prior pharmacologic prophylaxis therapies and whose medical state is managed for medication overuse (19). However, because it is not reimbursed in our country, it may be used by patients with CM who meet these criteria whose OLDU application is approved. During the 4 years studied, a total of 1685 patients with CM had applications for botilinum toxin A approval.

Another drug with most frequent applications after MS and CM drugs in our study was rituximab used for patients diagnosed with neuromyelitis optica (NMO). In the largest national OLDU rituximab study performed by O'Connor and Liddle (20) in Australia, $12 \%$ of patients for whom applications were made had neurologic diseases, and the most frequent diagnosis was NMO, as in our study. In a retrospective study in patients receiving rituximab performed by the National Autoimmune diseases Registry Unit in Germany, the patients' diagnosis percentages were $16.1 \%$ NMO, 28.6\% RRMS, 19.6\% SPMS, and 32.1\% PPMS (21). In our study, the most frequent diagnosis for rituximab applications was NMO, followed by MS, and MG.

MMF was another drug with frequent applications. MMF is promising in immune-mediated neuromuscular disorders. MMF has shown beneficial effects in patients with MG in preparatory studies and is currently being studied in two trials to generate a better understanding of its role in treatment (22). In our study, MMF was the most commonly prescribed off-label drug for MG.

Intravenous immunoglobulin (IVIG) has long been used in the treatment of several immune-mediated neurologic diseases. As the first-line treatment, it is used for Guillain-Barre syndrome, chronic inflammatory demyelinating polyneuropathy, and multifocal motor neuropathy. It is also beneficial in the treatment of $\mathrm{MG}$ exacerbations and has promising effects as a second-line therapy in patients who received inflammatory myopathy diagnoses (e.g. dermatomyositis, polymyositis, inclusion body myositis, and necrotizing autoimmune myositis), other neuropathies (diabetic amyotrophy, vasculitic neuropathy) and in some painful sensory neuropathies, such as those related to Sjögren's syndrome and Stiff-Person syndrome $(23,24,25,26,27)$. NMO, autoimmune encephalitides, Post-polio syndrome, and reflex sympathetic dystrophy were described as the more recent off-label uses of IVIG. In our study, off-label applications for IVIG were likewise made mainly for patients with steroid-irresponsive NMO and in patients with autoimmune encephalitides and diabetic amyotrophy $(28,29,30,31,32)$.

The strength of our study is that it is the most comprehensive study in neurology covering an extensive period of 4 years and comprising data including outpatient care data from all hospitals in the country, involving only real data. Other studies on OLDU 
in the world focused mostly on oncologic, pediatric, hospitalized, intensive care, and psychiatric patients $(33,34,35,36)$.

\section{Study Limitations}

However, this study has limitations. This was a retrospective analysis of medical records and there was no control groups or randomization. Despite these limitations, our study has the largest patient population $(n=9758)$ performed within the last decade investigating off-label drugs in neurology.

\section{Conclusion}

Our study focused on the long-term data of a variety of patient groups. Based on the country-wide data during the four years, our study investigated off-label neurology applications in our country and established good guidance for our physicians and healthcare professionals functioning in this field and made a significant contribution to the literature by offering a comparison with similar uses across the world.

\section{Ethics}

Ethics Committee Approval: Approval of the Ethics Board of the Medical Faculty of Cerrahpasa University was received on 04/08/2018 (45103048-604.01.01-45803).

Informed Consent: Current consent form obtained from patients.

Peer-review: Externally peer-reviewed.

\section{Authorship Contributions}

Concept: Ş.Y., Design: Ş.Y., N.U.A., H.R., Data Collection or Processing: B.B., A.A., H.G., Analysis or Interpretation: Ş.Y., H.R., Literature Search: Ş.Y., H.R., Writing: Ş.Y.

Conflict of Interest: No conflict of interest was declared by the authors.

Financial Disclosure: The authors declared that this study received no financial support.

\section{References}

1. Wittich CM, Burkle CM, Lanier WL. Ten common questions (and their answers) about off-label drug use. Mayo Clin Proc 2012;87:982-990.

2. Yi ZM, Zhai SD, Huang S, Wang TS, Liu F. Off-label prescriptions for adult neurological patients: a pilot survey in China. Int J Clin Pharm 2012;34:8187.

3. Lat I, Micek S, Janzen J, et al. Off-label medication use in adult critical care patients. J Crit Care 2011;26:89-94.

4. Herring C, McManus A, Weeks A. Off-label prescribing during pregnancy in the UK: an analysis of 18,000 prescriptions in Liverpool Women's Hospital. Int J Pharm Pract 2010;18:226-229.

5. Roila F, Ballatori E, Labianca R, et al. Off-label prescription of antineoplastic drugs: an Italian prospective, observational, multicenter survey. Tumori J 2009;95:647-651.

6. Saiyed MM, Ong PS, Chew L. Off-label drug use in oncology: a systematic review of literature. J Clin Pharm Ther 2017;42:251-258.

7. Ministry Of Health. Off- Labeled use of Drug Regulation. Circular No:2006/115. 2006 Nov 14. Available from: http://www.saglik.gov.tr/ TR, 10551/endikasyon-disi-ilac-kullanimi.html

8. Turkish Official Gazette. Turkish Medical Deontology Regulation Law No: 4/12578. 1960 Jan 13. Available from: http://www.resmigazete.gov.tr/ arsiv/10436.pdf

9. Turkish Official Gazette. Pharmaceutical and Medical Preparations Law. Law No: 1262. 1928 May 26. Available from: http://www.mevzuat.gov.tr MevzuatMetin/1.3.1262.pdf

10. Özdamar EN, Akıc1 A, Alkan A, Bayar B, Gürsöz H. A nationwide evaluation of off-label drug utilization in Turkey. Turk J Med Sci 2017;47:1229-1238.
11. Palumbo S. Pathogenesis and progression of multiple sclerosis: the role of arachidonic acid-mediated neuroinflammation. In: Zagon IS, McLaughlin PJ (eds). Multiple Sclerosis: perspectives in treatment and pathogenesis [Internet]. Brisbane (AU): Codon Publications 2017:111-125.

12. Grigoriadis N, van Pesch V, ParadigMS Group. A basic overview of multiple sclerosis immunopathology. Eur J Neurol 2015;22(Suppl 2):3-13.

13. Yurtoğulları Ş, Taşkapılıoğlu Ö, Öztürk B, et al. Comparison of brain atrophy, cognition and optical coherence tomography results between multiple sclerosis patients and healthy controls. Noro Psikiyatr Ars 2018;55:3-8.

14. Multiple Sclerosis İnternational Federation. The Atlas of MS 2013: mapping multiple sclerosis around the world. Multiple Sclerosis International Federation, 2013. Available from: http://www.msif.org/wp-content/ uploads/2014/09/Atlas-of-MS.pdf

15. Eraksoy M. Multipl skleroz ve diğer miyelin hastalıklar [Multiple sclerosis and other demyelinating diseases]. In: Emre M (ed). Nöroloji Temel Kitabı. 1st ed. Ankara: Güneş tıp kitapevi, 2013:1111-1141.

16. Negro A, Curto M, Lionetto L, Crialesi D, Martelletti P. OnabotilinumtoxinA $155 \mathrm{U}$ in medication overuse headache: a two years prospective study. Springerplus 2015;4:826.

17. Escher CM, Paracka L, Dressler D, Kollewe K. Botilinum toxin in the management of chronic migraine: clinical evidence and experience. Ther Adv Neurol Disord 2017;10:127-135.

18. Frampton JE, Silberstein S. OnabotilinumtoxinA: A review in the Prevention of Chronic migraine. Drugs 2018;78:589-600.

19. Schaefer SM, Gottschalk CH, Jabbari B. Treatment of Chronic Migraine with Focus on Botulinum Neurotoxins. Toxins 2015;7:2615-2628.

20. O'Connor K, Liddle C. Prospective data collection of off-label use of rituximab in Australian public hospitals. Intern Med J 2013;43:863-870.

21. Rommer PS, Dörner T, Freivogel K, et al. Safety and clinical outcomes of rituximab treatment in patients with multiple sclerosis and neuromyelitis optica: experience from a National Online Registry (GRAID). J Neuroimmune Pharmacol 2016;11:1-8.

22. Gotterer L, Li Y. Maintenance immunosuppression in myasthenia gravis. J Neurol Sci 2016;369:294-302.

23. Jann S, Bramerio MA, Facchetti D, Sterzi R. Intravenous immunoglobulin is effective in patients with diabetes and with chronic inflammatory demyelinating polyneuropathy: long term followup. J Neurol Neurosurg Psychiatry 2009;80:70-73.

24. Kawagashira Y, Watanabe H, Morozumi S, et al. Differential response to intravenous immunoglobulin (IVIg) therapy among multifocal and polyneuropathy types of painful diabetic neuropathy. J Clin Neurosci 2010;17:1003-1008.

25. Blaes F. Diagnosis and therapeutic options for peripheral vasculitic neuropathy. Ther Adv Musculoskelet Dis 2015;7:45-55.

26. Rist S, Sellam J, Hachulla E, et al. Experience of intravenous immunoglobulin therapy in neuropathy associated with primary Sjögren's syndrome: a national multicentric retrospective study. Arthritis Care Res (Hoboken) 2011;63:1339-1344.

27. Lünemann JD, Nimmerjahn F, Dalakas MC. Intravenous immunoglobulin in neurology--mode of action and clinical efficacy. Nat Rev Neurol 2015;11:80-89.

28. Lünemann JD, Quast I, Dalakas MC. Efficacy of intravenous immunoglobulin in Neurological Diseases. Neurotherapeutics 2016;13:34-46.

29. Elsone L, Panicker J, Mutch K, et al. Role of intravenous immunoglobulin in the treatment of acute relapses of neuromyelitis optica: experience in 10 patients. Mult Scler 2014;20:501-504.

30. Magraner MJ, Coret F, Casanova B. The effect of intravenous immunoglobulin on neuromyelitis optica. Neurologia 2013;28:65-72.

31. Titulaer MJ, McCracken L, Gabilondo I, et al. Treatment and prognostic factors for long-term outcome in patients with antiNMDA receptor encephalitis: an observational cohort study. Lancet Neurol 2013;12:157-165.

32. Goebel A, Baranowski A, Maurer K, et al. Intravenous immunoglobulin treatment of the complex regional pain syndrome: a randomized trial. Ann Intern Med 2010;152:152-158.

33. Saiyed MM, Ong PS, Chew L. Off-label drug use in oncology: a systematic review of literature. J Clin Pharm Ther 2017;42:251-258.

34. Vijay A, Becker JE, Ross JS. Patterns and predictors of off-label prescription of psychiatric drugs. PLoS One 2018;13:e0198363. 
35. Brown GP, Stewart LA, Rabinowitz T, Boudreau H, Wright AJ. Approved and Off-Label Use of Prescribed Psychotropic Medications among Federal Canadian Inmates. Can J Psychiatry 2018;63:683-691.
36. Nir-Neuman H, Abu-Kishk I, Toledano M, et al. Unlicensed and Off-Label Medication Use in Pediatric and Neonatal Intensive Care Units: No Change Over a Decade. Adv Ther 2018;35:1122-1132. 